\title{
Effect of Light-Curing Units, Post-Cured Time and Shade of Resin Cement on Knoop Hardness
}

\author{
Rogério Vieira REGES ${ }^{1,2}$ \\ Ana Rosa COSTA ${ }^{1}$ \\ Américo Bortolazzo CORRER ${ }^{1}$ \\ Evandro PIVA ${ }^{3}$ \\ Regina Maria PUPPIN-RONTANI ${ }^{4}$ \\ Mário Alexandre Coelho SINHORETI ${ }^{1}$ \\ Lourenço CORRER-SOBRINHO ${ }^{1}$ \\ ${ }^{1}$ Department of Restorative Dentistry, Dental Materials Division, Piracicaba Dental School, \\ State University of Campinas, Piracicaba, SP, Brazil \\ ${ }^{2}$ Dental School, Paulista University, Goiânia, GO, Brazil \\ ${ }^{3}$ Department of Restorative Dentistry, Dental School, Federal University of Pelotas, Pelotas, RS, Brazil \\ ${ }^{4}$ Department of Pediatric Dentistry, Piracicaba Dental School, State University of Campinas, Piracicaba, SP, Brazil
}

\begin{abstract}
The aim of this study was to evaluate the Knoop hardness after $15 \mathrm{~min}$ and $24 \mathrm{~h}$ of different shades of a dual-cured resin-based cement after indirect photoactivation (ceramic restoration) with 2 light-curing units (LCUs). The resin cement Variolink II (Ivoclar Vivadent) shade XL, A2, A3 and opaque were mixed with the catalyst paste and inserted into a black Teflon mold (5 mm diameter $\mathrm{x}$ $1 \mathrm{~mm}$ high). A transparent strip was placed over the mold and a ceramic disc (Duceram Plus, shade A3) was positioned over the resin cement. Light-activation was performed through the ceramic for $40 \mathrm{~s}$ using quartz-tungsten-halogen (QTH) (XL 2500; 3M ESPE) or light-emitting diode (LED) (Ultrablue Is, DMC) LCUs with power density of 615 and $610 \mathrm{~mW} / \mathrm{cm}^{2}$, respectively. The Koop hardness was measured using a microhardness tester HMV 2 (Shimadzu) after 15 min or 24 h. Four indentations were made in each specimen. Data were subjected to ANOVA and Tukey's test $(\alpha=0.05)$. The QTH LCU provided significantly higher $(\mathrm{p}<0.05) \mathrm{KHN}$ values than the LED LCU. When the post-cure times were compared for the same shade, QTH and LED at $24 \mathrm{~h}$ provided significantly higher $(p<0.05) \mathrm{KHN}$ values than at $15 \mathrm{~min}$. It may be concluded that the Knoop hardness was generally dependent on the LCU and post-cure time. The opaque shade of the resin cement showed lower Knoop hardness than the other shades for both LCUs and post-cure times.
\end{abstract}

Key Words: Knoop hardness, dental ceramic, resin cement, light-curing unit.

\section{INTRODUCTION}

Resin-based luting cements have been recommended for the cementation of ceramic inlays (1). After cementation, an adequate polymerization of the luting cement is necessary (2). The curing of the resin cement might be influenced by the light absorption and dispersion within the cement, shade, chemical composition, filler particle size the power density delivered by the curing unit and the irradiation time (3-6). Inadequate polymerization is associated with an increased water sorption and solubility, lower color stability and poor mechanical properties (7-9).

In addition, the light attenuation effect promoted by ceramics might reduce the amount of light reaching the bottom of the cavity, and compromise the photoactivation of the luting material (10). The degree of this attenuation is dependent on the characteristics of the restorative material, shade, opacity and thickness, which interfere with light transmittance and, as a result, the polymerization process $(4,6,8,10,11)$. The combination of scattering, reflecting and absorbing properties at the outer surface of the intervening material may explain the reduction in the incident light (12). 
Light curing is usually done with quartz-tungstenhalogen (QTH) light-curing units (LCUs). This type of LCU emits light from a halogen bulb, which is filtered by a dielectric pass-band filter to remove the undesirable wavelengths $(9,13)$. Other technologies, such as lightemitting-diodes (LEDs) are also available. LED is formed by junctions of doped semiconductors (p-n junctions) to generate light and, hence, require no filters to produce blue light with narrower spectral (440-490 nm) falls within the camphoroquinone absorption spectrum (468 nm) (14).

This study evaluated the Knoop hardness values after $15 \mathrm{~min}$ and $24 \mathrm{~h}$ of different shades of a dual-cured resin cement after indirect photoactivation (ceramic restoration) with 2 LCUs. The null hypotheses tested were: (1) the two post-cure times, $15 \mathrm{~min}$ and $24 \mathrm{~h}$, have similar influence on hardness; (2) hardness is similar for different cement shades; and (3) the LCUs do not influence the hardness of the dual-cure resin cement.

\section{MATERIAL AND METHODS}

Feldspathic ceramic (Duceram Plus; Ducera Dental, Robasch, Germany, shade dentin A3) was condensed into a stainless steel mold ( $8 \mathrm{~mm}$ inner diameter $\mathrm{x} 2 \mathrm{~mm}$ high) and the disc was fired in ceramic furnace (Austromat M; Dekema Austromat-Keramiköfen, Freilassing, Germany), and then subjected to wet polishing with 220-, 400-, 600- and 1200-grit SiC papers (Norton S.A., São Paulo, SP, Brazil) and prepared with glaze firing, according to manufacturer's instructions.

Variolink II dual cure resin cement (IvoclarVivadent, Schaan, Liechtenstein) was used the material tested in this study. Different shades of base paste XL, A2, A3 and Opaque were mixed with the catalyst paste, according to manufacturer's directions and inserted into a black Teflon mold with $5 \mathrm{~mm}$ in diameter and $1 \mathrm{~mm}$ in deep. A transparent polyester strip was placed ontothe mold and the ceramic disc was positioned over the resin cement. Light-activation was performed through the ceramic for $40 \mathrm{~s}$, using QTH (XL 2500; 3M/ESPE, St. Paul, MN, USA) or LED (D.M.C. Equipamentos Ltda, São Carlos, SP, Brazil) LCUs with irradiance of 615 and $610 \mathrm{~mW} / \mathrm{cm}^{2}$, respectively (Fig. 1).

Forty specimens were obtained for each cement shade. These specimens were separated into 2 groups according to the LCU: LED and QTH. Half of the specimens were tested after $15 \mathrm{~min}$ and half after dry storage for $24 \mathrm{~h}$ in light-proof containers at $37^{\circ} \mathrm{C}(\mathrm{n}=10)$. Next, the specimens were fixed in an acrylic resin die with stick wax and transversely wet-flattened with 320-, 400-, 600- and 1200-grit SiC papers (Norton SA).

Knoop hardness measurements were done using a microhardness tester HMV 2 (Shimadzu Corp., Tokyo, Japan) with a load of $50 \mathrm{~g}$ applied for $15 \mathrm{~s}$. Four indentations were made in the cross-sectional area at $100 \mu \mathrm{m}$ from the top surface. The average value of the 4 readings was recorded as Knoop Hardness Number (KHN).

Data were subjected to 3-way ANOVA (post-cure time $\mathrm{x}$ curing units $\mathrm{x}$ shade). Comparison of $\mathrm{KHN}$ values among the groups was done by Tukey's test $(\alpha=0.05)$.

\section{RESULTS}

Table 1 showed that when QTH was compared to LED at $15 \mathrm{~min}$, statistically significant difference $(p<0.05)$ from KHN was found for shades A2, A3 and opaque. No significant difference $(p>0.05)$ was found for XL. After $24 \mathrm{~h}$, statistically significant difference for KHN was found between QTH and LED for XL, $A 2$ and $A 3$ shades $(p<0.05)$. No significant difference ( $>0.05$ ) was found for opaque.

When the KHN at 15 min was analyzed among the shades for each LCU, opaque shade showed lower hardness values with significant difference $(\mathrm{p}<0.05)$ from XL, A2 and A3 for QTH and LED LCUs. No significant difference $(\mathrm{p}>0.05)$ was found among $\mathrm{XL}$, $\mathrm{A} 2$ and $\mathrm{A} 3$ for QTH and between A2 and A3 for LED.

After $24 \mathrm{~h}$, the opaque shade showed lower KHN values with statistically significant difference $(p<0.05)$ in relation to XL, A2 and A3 for the QTH.

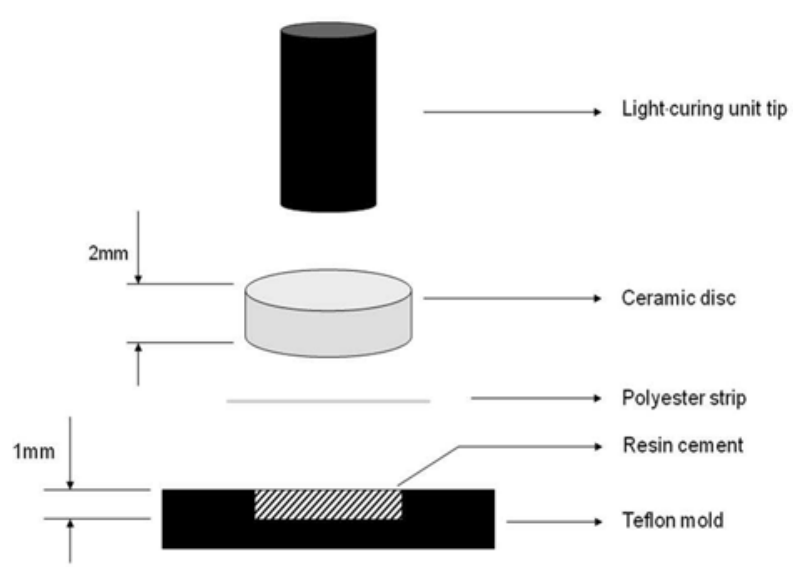

Figure 1. Schematic illustration of speciment preparation. 
No difference was found among XL, A2 and A3 $(\mathrm{p}>0.05)$. For LED, the opaque shade showed lower hardness values with statistically significant difference $(p<0.05)$ from XL. No difference was found among A2, $\mathrm{A} 3$ and opaque and XL and between XL and A2 ( $>>0.05)$.

For both LCUs and all shade of the resin cement, the time $24 \mathrm{~h}$ showed significantly higher $(\mathrm{p}<0.05)$ Knoop hardness values than $15 \mathrm{~min}$.

\section{DISCUSSION}

Bonded all-ceramic restorations are popular with clinicians and patients because of their superior esthetics: notably the diffuse transmission combined with diffuse and spectral reflectance of light that mimics the depth of translucency and color of natural teeth (15). However, clinical success with these restorations requires that they are bonded to teeth with high-strength, low solubility, and thin-film adhesives commonly light polymerized resin luting agents (8). Several factors can influence the polymerization degree of a resin cement, for instance, the ceramic shade and thickness, the LCU, and the curing time $(4,5,6,10)$. Resin cement polymerization depends upon the light absorption and dispersion within the cement, the shade and opacity of the composite resin (3).

The first null hypothesis was rejected. For the 2 LCUs and all shade of the resin cement, the time 24 $\mathrm{h}$ showed higher Knoop hardness values than $15 \mathrm{~min}$. Dual-cured cements have been recommended to luting ceramic or resin composite inlays to compensate for the attenuation of the curing light effect by the indirect restorative with ceramic, and to ensure adequate polymerization of the luting agent even at the bottom of the

Table 1. Means (standard deviation) Knoop hardness for the different shades of resin cement, post-cure times and light-curing units.

\begin{tabular}{lccccc}
\hline \multirow{2}{*}{$\begin{array}{l}\text { Post-cure } \\
\text { time }\end{array}$} & $\begin{array}{c}\text { Light- } \\
\text { curing unit }\end{array}$ & \multicolumn{5}{c}{ Shade of resin cement } \\
\cline { 3 - 6 } & XL & A2 & A3 & Opaque \\
\hline $15 \mathrm{~min}$ & QTH & $41.77(3.2) \mathrm{Aa}$ & $39.48(3.9) \mathrm{Aa}$ & $38.34(4.1) \mathrm{Aa}$ & $34.78(5.4) \mathrm{Ab}$ \\
$15 \mathrm{~min}$ & LED & $40.18(3.3) \mathrm{Aa}$ & $35.57(3.8) \mathrm{Bb}$ & $34.33(3.1) \mathrm{Bb}$ & $27.77(2.5) \mathrm{Bc}$ \\
$24 \mathrm{~h}$ & QTH & $* 59.46(3.0) \mathrm{Aa}$ & $* 55.58(2.5) \mathrm{Aa}$ & $* 58.29(3.5) \mathrm{Aa}$ & $* 45.52(5.9) \mathrm{Ab}$ \\
$24 \mathrm{~h}$ & LED & $* 53.34(4.7) \mathrm{Ba}$ & $* 49.57(5.4) \mathrm{Bab}$ & $* 48.48(3.9) \mathrm{Bb}$ & $* 46.48(4.9) \mathrm{Ab}$ \\
\hline
\end{tabular}

Means followed by different lowercase letters in the same row and uppercase letters in the same column are significantly different (Tukey's test, $\mathrm{p}<0.05$ ). * The values are statistically higher from those in columns (comparisons for the same shade). cavity access for the curing light is limited $(4,10,13,16)$. The results for shades XL, A2 and A3, suggest that sufficient light energy for polymerization was delivered to the specimens. It might be speculated that this could have left low amounts of remaining monomers available for conversion, thus hindering the chemical curing effect (4).

The second null hypothesis was rejected. The opaque group showed lower hardness values with statistical differences in relation another shades for the QTH and LED LCUs (Table 1) suggested that each shade might require a specific activation strategy to maximize hardness. Care should be taken when using opaque cements to increase the light exposure time to obtain a similar polymerization potential as that of the lighter shades (4). Shortall (17) reported that the opaque shades had the lowest depths of cure. Leloup et al. (18) showed that the polymerization depend upon light dispersion within the material. The pigments in darker shades might absorb more light and reduce its penetration into the composite. Besides, increasing the polymerization time for opaque specimens did not increase the degree of conversion, whatever the specimens thickness.

On the other hand, according to Table 1, the third null hypothesis was rejected. The light transmission also depends on LCU $(4,6,10)$. In general, higher hardness values were obtained with QTH in comparison to LED, except to light curing through resin cement shade XL (15 $\mathrm{min}$ ) and Opaque shade ( $24 \mathrm{~h}$ ). The large amount of infrared light emitted from QTH units produces great amount of heat, which is filtered out and discarded by means of intense fan-cooling (19). Normally, not only light energy, but also the additional thermal increased is responsible for conversion (20). However, Tango et al. (6) showed that higher hardness values were obtained with LED in comparison to QTH. It has been previously reported that LED units are the most efficient ones, because they are capable of converting electrical current into the correct wavelength, similar to the absorption wavelength of camphorquinone (12).

The irradiance of light source, the exposure time and light transmission 
of irradiated material are significant variables that affect the hardness or conversion profile $(1,10)$. Additionally, the light cure resin composites is affected by the chemical composition, filler particle size, shade, light intensity, duration of exposure, and the thickness of the overlying resin or porcelain $(10,13,19)$. Thus, adequate polymerization of resin cement is crucial for obtaining optimal physical and biological properties and clinical performance.

In this study, the QTH LCU provided higher KHN values than the LED LCU. When the post-cure time was compared for the same shade, QTH and LED at $24 \mathrm{~h}$ provided higher $\mathrm{KHN}$ values than at $15 \mathrm{~min}$. It may be concluded that the Knoop hardness was generally dependent on the LCU and post-cure time. The opaque shade of the resin cement showed lower hardness than the other shades for both LCUs and post-cure times.

\section{RESUMO}

Este estudo avaliou a dureza Knoop após 15 min e 24 h de diferentes cores do cimento resinoso dual após fotoativação indireta com 2 fontes de luz. O cimento resinoso Variolink II (Ivoclar Vivadent) nas cores XL, A2, A3 e opaco foram misturados com a pasta catalisadora e inseridos dentro de um molde de teflon preto com ( $5 \mathrm{~mm}$ de diâmetro x $1 \mathrm{~mm}$ de espessura). A tira de poliéster transparente foi inserida sobre o molde e um disco da cerâmica (Duceram Plus, cor A3) foi posicionada sobre o cimento resinoso. A fotoativação foi realizada sobre o disco de cerâmica por $40 \mathrm{~s}$ usando a lâmpada de luz halógena (XL 2500, 3M ESPE) ou luz emitida por diodo (LED) com intensidade de luz de 615 e 610 $\mathrm{mW} / \mathrm{cm}^{2}$. A dureza Knoop foi medida usando o microdurômetro HMV 2 (Shimadzu) com carga de 50 g por $15 \mathrm{~s}$, após 15 min e $24 \mathrm{~h}$. Quatro indentações foram feitas em cada amostra. Os dados foram submetidos à Análise de Variância e ao teste de Tukey $(\alpha=5 \%)$. A fonte de luz halógena promoveu valores de dureza significantemente maiores $(\mathrm{p}<0,05)$ que o LED. Quando os tempos pós-polimerização foram comparados para a mesma cor, a luz halógena e o LED promoveram valores de dureza significantemente maiores $(p<0,05)$ em 24 h do que aos 15 min. Pode-se concluir que, de maneira geral, a dureza Knoop foi dependente da fonte de luz e do tempo pós-polimerização. A cor opaca do cimento resinoso mostrou menores valores de dureza Knoop que as outras cores para ambas as fontes de luz e tempos pós-polimerização.

\section{ACKNOWLEDGEMENTS}

The authors are grateful to $\mathrm{CNPq} / \mathrm{Brazil}$ for financial support (Grant 308128/2006-0).

\section{REFERENCES}

1. Blatz MB, Sadan A, Kern M. Resin-ceramic bonding: a review of the literature. J Prosthet Dent 2003;89:268-274.
2. Moraes RR, Correr-Sobrinho L, Sinhoreti MA, Puppin-Rontani RM, Ogliari FA, Piva E. Light-activation of resin cement through ceramic: relationship between irradiance intensity and bond strength to dentin. J Biomed Mat Res B Appl Biomater 2008;85B:160-165.

3. Satterthwaite JD, Vogel K, Watts DC. Effect of resin-composite filler particle size and shape on shrinkage-strain. Dent Mater 2009;25:1612-1615.

4. Reges RV, Moraes RR, Correr AB, Sinhoreti MAC, Piva E, Nouer PRA, et al.. In-depth polymerization of dual-cured resin cement assessed by hardness. J Biomater Appl 2008;23:85-96.

5. Spinell T, Schedle A, Watts DC. Polymerization shrinkage kinetics of dimethacrylate resin-cements. Dent Mater 2009;25:1058-1066.

6. Tango RN, Sinhoreti MAC, Correr AB, Correr-Sobrinho L, Consani RLX. Effect of vennering materials and curing methods on resin cement Knoop hardness. Braz Dent J 2007;18:235-239.

7. Danesh G, Davids H, Reinhardt KJ, Ott K, Schafer E. Polymerisation characteristics of resin composites polymerised with different curing units. J Dent 2004;32:479-488.

8. Rasetto FH, Driscoll CF, Prestipino V, Masri R, von Franhofer JA. Light transmission through all-ceramic dental materials: a pilot study. J Prosthet Dent 2004;91:441-446.

9. Dalli'Magro E, Sinhoreti MA, Correr AB, Consani RL, Sicoli EA, Mendoça MJ, et al.. Effect of different modes of light modulation on the bond strength and Knoop hardness of a dental composite. Braz Dent J 2008;19:334-340.

10. Dias MC, Piva E, Moraes RR, Ambrosano GMB, Sinhoreti MAC, Correr-Sobrinho L. UV-Vis Spectrophotometric analysis and light irradiance through hot-pressed and hot-pressed-veneered glass ceramics. Braz Dent J 2008;19:197-203.

11. Soares CJ, da Silva NR, Fonseca RB. Influence of the feldspathic ceramic thickness and shade on the microhardness of dual resin cement. Oper Dent 2006;31:384-389.

12. Heffernan MJ, Aquilino SA, Diaz-Arnold AM, Haselton DR, Stanford CM, Vargas MA. Relative translucency of six all-ceramic systems. Part II: core and veneer materials. J Prosthet Dent 2002;88:10-15

13. Hofmann N, Papsthart G, Hugo B, Klaiber B. Comparison of photo-activation versus chemical or dual-curing of resin-based luting cements regarding flexural strength, modulus and surface hardness. J Oral Rehabil 2001;28:1022-1028.

14. Kurachi C, Tuboy AM, Magalhães DV, Bagnato VS. Hardness evaluation of a dental composite polymerized with experimental LED-based devices. Dent Mater 2001;17:309-315.

15. Correr AB, Sinhoreti MA, Sobrinho LC, Tango RN, Schneider LF, Consani S. Effect of the increase of energy density on Knoop hardness of dental composites light-cured by conventional QTH, LED and xenon plasma arc. Braz Dent J 2005;16:218-224.

16. Lee IB, Um CM. Thermal analysis on the cure speed of dual cured resin cements under porcelain inlays. J Oral Rehabil 2001;28:186-197.

17. Shortall AC. How light source and product shade influence cure depth for a contemporary composite. J Oral Rehabil 2005;32:906-911.

18. Leloup G, Holvoet PE, Bebelman S, Devaux J. Raman scattering determination of the depth of cure of light-activated composites: influence of different clinically relevant parameters. J Oral Rehabil 2002;26:510-515.

19. Oberholpez G, Botha CT, du Preez IC. Advances in light curing units and curing techniques: a literature review. SADJ 2005;60:451-454.

20. Stansbury JW. Curing dental resins and composites by photopolymerization. J Esthet Dent 2000;12:300-308.

Accepted November 19, 2009 